\title{
Environmental health Effect and Air Pollution from cigarette smokers in Cross River State, Nigeria
}

\author{
Obi, E. O. ${ }^{1}$, Osang, J. E. ${ }^{1}$, Ewona, I. O. ${ }^{1}$, Udoimuk A. B. ${ }^{2}$ \\ Kamgba, F. A ${ }^{1}$, \\ 1. Department Of Physics, Cross River University Of Technology Calabar, Nigeria \\ 2. Department Of Physics University Of Calabar ,Calabar.
}

\begin{abstract}
This study is aimed at assessing the cause of air pollution and Environmental health effect on people living in Cross River State using cigarette smokers as a case study. Data was gathered through a well designed and articulated oral and written questionnaires, direct and first-hand observation of the environment, and comprehensive interview sessions were carried out with community Heads (Royal Authorities where possible), patients and youths. A total of one hundred and seventeen thousand $(117,000)$ questionnaires were randomly distributed evenly to men of about 20-75years old in all the Eighteen (18) Local Government Area in Cross River State. Eighty seven thousand, five hundred and thirty three (87,533) valid questionnaire were received back. Nine hundred (900) of the people reported that they do not smoke any cigarette. Table 1 shows the total number of people who smoke cigarette. Table 2a,b show the total number of patients with smoking related diseases. Most of these patients with smoking related diseases such as decrease in lung function, increase of heart attack, Respiratory diseases, cancer, asthma, and other health effects are having those disease conditions as a result of their smoking habits.
\end{abstract}

Keyword: Cross River State, Cigarette smokers, Air Pollution, and Environmental health effect.

\section{Introduction}

Air is one of the major components that man needs to survive. Therefore the quality of air we breathe has a greater contribution to the comfort of man's existence on earth. And as such, the source of air and its composition are very important in this study. It does not matter who you are, where you live or the state of your health, the quality of air you breathe each day affects you. (Osang et al 2013). A lot of chemicals and gases are generated in smoking cigerette. Precautionary measures against inhalation of those chemicals and gases are generally poor or non-existent owing to lack of resources by the management of the industries and ignorance in the part of the public (Robert D. Bullard 2002, Osang et al 2013 ). Ever since people first gathered, there has been pollution. Pollution usually refers to the presence of substances that are either present in the environment where it doesn't belong or at levels greater than it should be.(Osang et al 2013). Air pollution is caused by any undesirable substance, which enters the atmosphere. Air pollution is a major problem in modern society. Even though air pollution is usually a greater problem in cities, pollutants contaminate air anywhere everywhere (Osang et al 2013) . These substances include various gases and tiny particles, or particulates that can harm human health and damage the environment (Obi et al 2008, Ewona et al 2012). The major hazardous pollutants in urban cities are carbon monoxide, nitric oxide, sulphur dioxide, ozone, particulate matter and smog which is contributed greatly by cigarette smokers. They may be gases, liquids, or solids. Many pollutants are given off into the air as a result of human behavior (Osang et al 2013). Pollution occurs in different levels: personal, national, and global. Air pollution is mainly composed of gas and particulate matter (PM) (Obi et al 2009). The main gases that contaminate the air are ozone $\left(\mathrm{O}_{3}\right)$, nitrogen dioxide $\left(\mathrm{NO}_{2}\right)$, sulphur dioxide $\left(\mathrm{SO}_{2}\right)$, and carbon monoxide (CO). PM can be classed according to size: PM of less than 10 micrometers $\left(\mathrm{PM}_{10}\right)$ and $\mathrm{PM}$ of less than 2.5 micrometers $\left(\mathrm{PM}_{2.5}\right)$. The smaller particles can penetrate deep into the lungs damage to the ozone layer is primarily caused by the use of chlorofluorocarbons (CFCs). Ozone is a form of Oxygen found in the earth's upper atmosphere. The thin layer of ozone molecules in the atmosphere absorb some of the sun's ultraviolet (UV) rays before it reaches the earth's surface, making life on earth possible. The depletion of ozone is causing higher levels of UV radiation on earth, endangering both plants and animals (Obi et al 2008, Ekpenyong et al. 2013, Osang et al 2013).

Every year, there are 50 million cases of occupational respiratory diseases caused by inhalation of toxic dust and chemicals, which are allergenic and carcinogenic agents. (Urom et al 2004). According to the World Health Organization (WHO), about one-third of Africa's disease burden is attributable to environmental hazards. The major contributing risk factors to environmental disease burden in the continent are traditional environmental health hazards such as air pollution (Onyemaechi et al, 2009). The global estimate made by the United Nations Environment Programme shows that 1.1 billion people breathe unhealthy air. This increases daily deaths and hospital admissions throughout the world, because of its wide range of effects on human 
health, especially related to the cardiopulmonary system. It is also estimated that, urban air pollution is responsible for approximately 800000 deaths and 4.6 million loss of lives each year around the globe. (Ekpenyong et al. 2013). Outdoor air pollution, in particular has emerged as an issue in the last few decades, particularly in Africa's Urban Centers because of increased rates of urbanization and industrialization. Sources of indoor and outdoor air pollution include pesticides used in the home and cigarette smoking. An important contributor to air pollution in Africa's Cities is emissions of different sources (Onyemaechi et al, 2009).

Empirical evidences have shown that these inhaled substances have strong pulmonary and systemic inflammatory potential and can cause irritation and allergy in the lungs and air passages of individuals who are exposed to them for a long time( Osang et al 2013). Some epidemiologic studies have been conducted to evaluate the health effects (particularly respiratory effects) of indoor and outdoor air pollution exposure on African populations. According to the authors, "the studies provide some evidence of associations with a range of serious and common health problems (Onyemaechi et al, 2009). However, the type of disease developed may depend on the size of the particles or what is inhaled and where it ends up in the airways or lungs. In some cases, larger particles tend to end up trapped in the nose or larger airways. Small particles on the order of 10 micrometers $\left(\mathrm{PM}_{10}\right)$ or less $\left(\mathrm{PM}_{2.5}\right.$ and $\left.\mathrm{UFP}_{\mathrm{s}}\right)$ can penetrate the deepest part of the lungs such as bronchioles or alveoli. Sometimes, they get dissolved and absorbed into the blood stream, eliciting greater biological effects. The composition, concentration and associated toxicity of specific ambient air pollutants as well as the duration and frequency of exposure will determine the adverse health effects and the clinical respiratory manifestations. For example, ambient air pollutants with predominant particulate matter, ozone $\left(\mathrm{O}_{3}\right)$ and $\mathrm{NO}_{2}$ have been shown to exacerbate airway oxidative stress, bronchial reactivity, respiratory viral infection and reduced airway ciliary activity. Also, particulate matters can facilitate the development of lung cancer and increase mortality (Osang et al 2013, Ekpenyong et al. 2013).

The spectrum and severity of adverse respiratory health effects of the inhaled pollutants may vary from subclinical effects to premature mortality, depending on the degree of exposure by various occupations, environmental factors, sociodemographics and population sensitivities. Lung diseases following occupational exposure among Nigerians have been extensively studied. (Osang et al 2013, Ewona et al 2011 ).

Nigeria is one of the highest emitter of greenhouse gases in Africa. Carbon dioxide emissions in Niger Delta Area are among the highest in the world. (Ewona 2011). Outdoor ambient air pollution is a major threat to human health in most West African big Cities including Nigeria and other parts of the world. It reduces the life expectancy of people who are constantly exposed to it. According to Ewona et al (2012), referring to IPPC (1992), the major cause of climate change is the release of greenhouse gases. Some of these gases especially $\mathrm{CO}_{2}$ and oxides of Nitrogen are dissolved in rain water and fall back as acid rain which will in turn pollute the air (Ekpenyong et al. 2013, Osang et al 2013, Ewona et al 2012)

In Nigeria, various studies have indicated a high level of ambient air pollution in most urban cities especially the Niger Delta region, of which the Cross River State, is an integral part. A typical air quality assessment of this region shows that the levels of volatile oxides of carbon, nitrogen, sulphur and total particulate matter exceed the existing Federal Agency Standards. Common sources of air pollution in this area include: cigarette smoking, bush burning, automobile emissions, generators emission, pipeline explosion, industrial emissions and gas flaring (Ekpenyong et al. 2013, Ewona et al 2012).

\section{Health effects of tobacco}

The health effects of Smoking are the circumstances, mechanisms, and factors of tobacco consumption on human health. Epidemiological research has been focused primarily on cigarette tobacco smoking(World Health Organization (2008)) which has been studied more extensively than any other form of consumption.

Tobacco is the single greatest cause of preventable death globally. The use of Tobacco leads to most common diseases affecting the heart, liver and lungs, with smoking being a major risk factor for heart attacks, strokes, chronic obstructive pulmonary disease (COPD) (including emphysema and chronic bronchitis), and cancer (particularly lung cancer, cancers of the larynx and mouth, and pancreatic cancer). It also causes peripheral vascular disease and hypertension (Robert Bullard 2013). The effects depend on the number of years that a person smokes and on how much the person smokes. Starting smoking earlier in life and smoking cigarettes higher in tar increases the risk of these diseases. Also, environmental tobacco smoke, or secondhand smoke, has been shown to cause adverse health effects in people of all ages . Cigarettes sold in underdeveloped countries tend to have higher tar content, and are less likely to be filtered, potentially increasing vulnerability to tobacco-related disease in these regions (Fowles 2003).

The World Health Organization (WHO) estimates that tobacco caused 5.4 million deaths in 2004 and 100 million deaths over the course of the 20th century. Similarly, the United States Centers for Disease Control and Prevention describes tobacco use as "the single most important preventable risk to human health in developed countries and an important cause of premature death worldwide." Several countries including Nigeria 
have taken measures to control the consumption of tobacco with usage and sales restrictions as well as warning messages printed on packaging (Nichter 1991).

Smoke contains several carcinogenic pyrolytic products that bind to DNA and cause many genetic mutations. There are 45 known or suspected chemical carcinogens in cigarette smoke (Vanio 1987). Tobacco also contains nicotine, which is a highly addictive psychoactive drug. When tobacco is smoked, nicotine causes physical and psychological dependency. Tobacco use is a significant factor in miscarriages among pregnant smokers, and it contributes to a number of other threats to the health of the fetus such as premature births and low birth weight and increases by 1.4 to 3 times the chance for Sudden Infant Death Syndrome (SIDS). The result of scientific studies done in neonatal rats seems to indicate that exposure to cigarette smoke in the womb may reduce the fetal brain's ability to recognize hypoxic conditions, thus increasing the chance of accidental asphyxiation. Incidence of impotence is approximately 85 percent higher in male smokers compared to nonsmokers, and is a key factor causing erectile dysfunction (ED) (Fowles 2003).

\section{Materials and method}

STUDY AREA:

Calabar Metropolis is the capital of Cross River State, which is one of Nigeria's coastal State, located in the south-south region of the county, bordered by the Republic of Cameroon in the East and Nigeria state of Benue (North), Ebonyi and Abia (West) and Akwa Ibom (south-west ). It occupies a total land area of 10,156 square kilometers, lying between latitude $4^{0} 28^{0}$ and $6^{0} 55^{\circ}$ North of the equator and longitude $7^{0} 5^{0}$ and $9^{0} 28^{0}$ East of Greenwich meridian (Osang et al 2013).

Data source

Data was gathered through well designed and articulated oral and written questionnaires, direct and firsthand observation of the environment, and comprehensive interview sessions with community Heads (Royal Authorities where possible), patients and youth. A total number of one hundred and seventeen thousand $(117,000)$ questionnaires were randomly distributed evenly to only men of about $15-75$ years old in all the Eighteen (18) Local Government Areas in Cross River State as design in table 1 below. The questionnaires are administered through the help of all the Paramount Rullers, Clan Heads, Chiefs and Community Executives in all the 18 Local Government Areas. Eighty eight thousand,nine hundred and one $(88,901)$ questionnaires were recovered and four hundred and sixty eight (468) were not valid for analyses. Eighty seven thousand, five hundred and thirty three $(87,533)$ of valid questionnaire were recorded. Nine hundred (900) numbers of people do not smoke any of the cigarette, and as such were not recorded. While one thousand five hundred smokers were interviewed in each Local Government Area. Table 2a,b shows the total number of patience with smoking related disease. Descriptive analyses using simple bar chart and pie chart indicating Local Government Area, No of smokers, Minimum Quantity of Cigarette consumed per person per day, Maximum. Quantity of Cigarette consumed per person per day, Total Quantity of Cigarette consummed per person per day, Average Quantity of Cigarette consummed per person per day were carried out.

\section{Results}

\begin{tabular}{|c|c|c|c|c|c|c|}
\hline $\mathrm{S} / \mathrm{N}$ & $\begin{array}{c}\text { Local } \\
\text { Government } \\
\text { Area } \\
\end{array}$ & $\begin{array}{c}\text { No of } \\
\text { smokers }\end{array}$ & $\begin{array}{c}\text { Min. Qty of } \\
\text { Cigarette consumed } \\
\text { per person daily }\end{array}$ & $\begin{array}{c}\text { Max. Qty of } \\
\text { Cigarette consumed } \\
\text { per person daily }\end{array}$ & $\begin{array}{l}\text { Total Quantity of } \\
\text { Cigarette per } \\
\text { person daily }\end{array}$ & $\begin{array}{c}\text { Average } \\
\text { Quantity of } \\
\text { Cigarette per } \\
\text { person daily }\end{array}$ \\
\hline 1 & Akpabuyo & 5,111 & 2 & 48 & 50 & 25 \\
\hline 2 & Akamkpa & 4,900 & 1 & 43 & 44 & 12 \\
\hline 3 & Odukpani & 4,513 & 1 & 27 & 28 & 14 \\
\hline 4 & Biase & 4,614 & 1 & 31 & 32 & 16 \\
\hline 5 & Ikom & 4,738 & 1 & 29 & 30 & 15 \\
\hline 6 & Yarkulr & 4,811 & 1 & 27 & 28 & 14 \\
\hline 7 & Obubra & 4,621 & 2 & 26 & 28 & 14 \\
\hline 8 & Boki & 4,824 & 1 & 43 & 40 & 20 \\
\hline 9 & Ogoja & 4,715 & 1 & 43 & 44 & 22 \\
\hline 10 & Calabar- South & 6,116 & 2 & 58 & 60 & 30 \\
\hline 11 & Etung & 4,613 & 2 & 38 & 40 & 20 \\
\hline 12 & Bekwara & 4,656 & 1 & 37 & 38 & 19 \\
\hline 13 & Bakassi & 4,920 & 2 & 50 & 52 & 26 \\
\hline 14 & $\begin{array}{l}\text { Calabar } \\
\text { Municipality }\end{array}$ & 6,071 & 3 & 55 & 58 & 29 \\
\hline 15 & Obanliku & 4,481 & 1 & 39 & 40 & 20 \\
\hline 16 & Obudu & 4,857 & 2 & 32 & 34 & 17 \\
\hline
\end{tabular}




\begin{tabular}{|l|l|l|l|l|l|l|}
17 & Yala & 4,112 & 2 & 40 & 42 & 21 \\
\hline 18 & Abi & 4,860 & 2 & 42 & 44 & 20 \\
\hline
\end{tabular}

TABLE 1: STATISTICS OF SMOKERS IN CROSS RIVER STATE, NIGERIA.

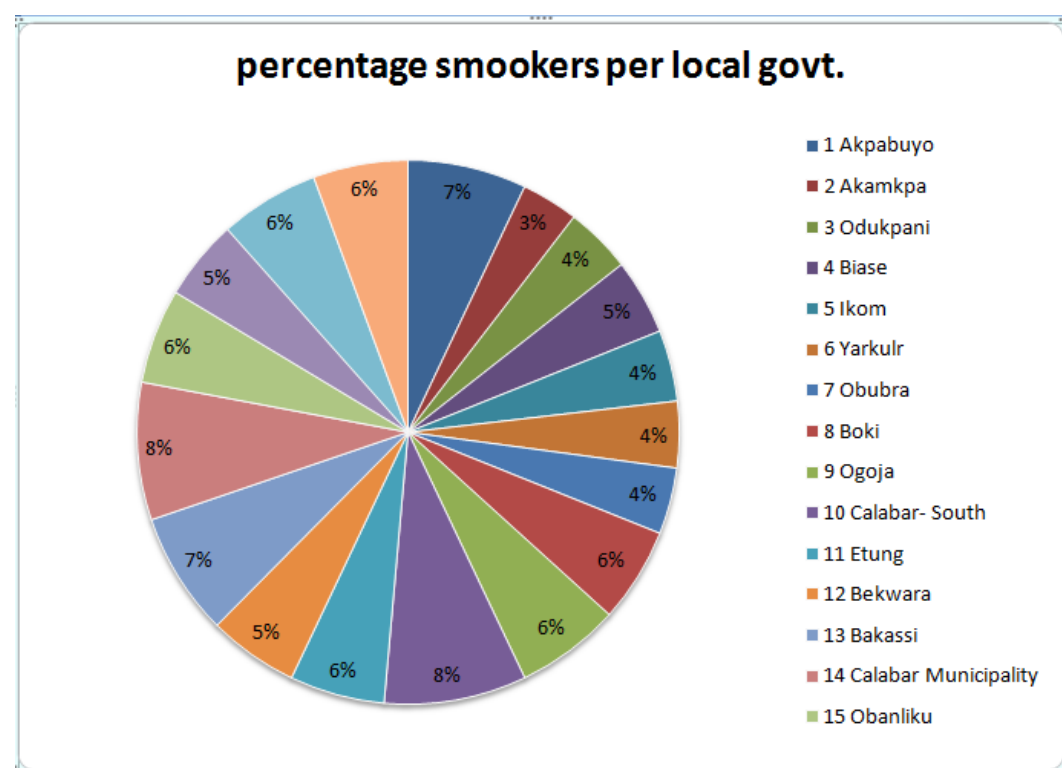

Fig. 1: Descriptive Pie Chart Of Smookers Per Local Government Area In Cross River State, Nigeria.

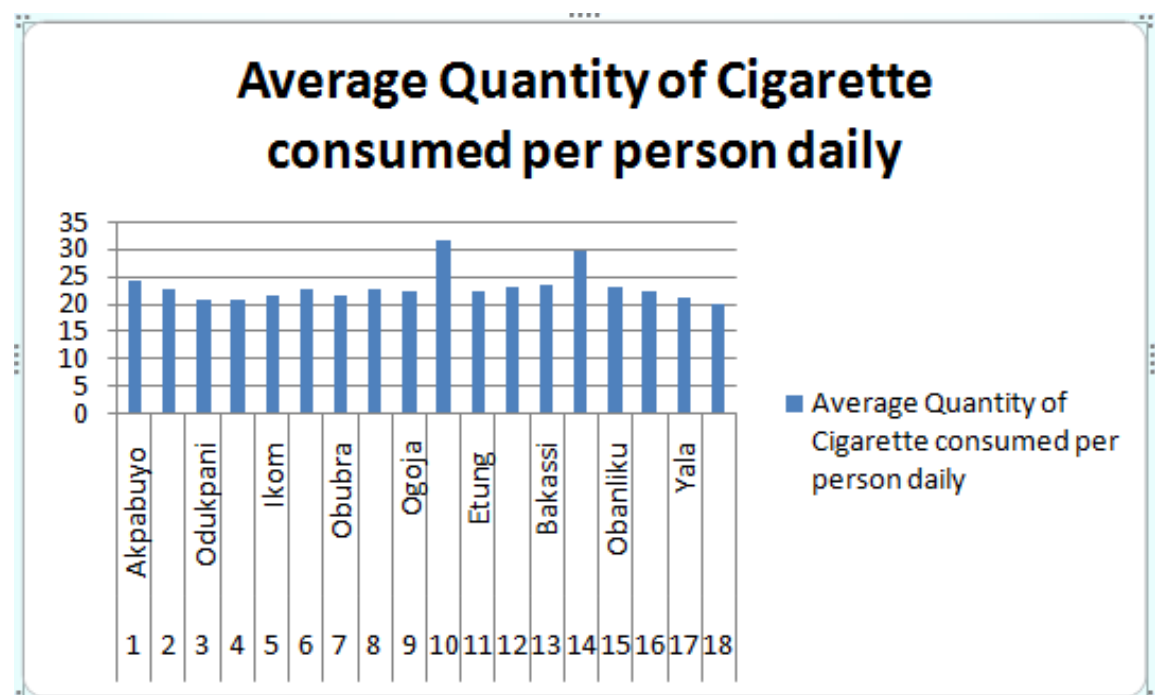

Fig. 2: descriptive comparable bar chart of Average Quantity of Cigarette consumed per person daily in some L.G.A. in C.R.S. 
Environmental health Effect and Air Pollution from cigarette smokers in Cross River State, Nigeria

\begin{tabular}{|c|c|c|c|c|}
\hline $\mathbf{S} / \mathbf{N}$ & Local Government Area & DIESASES & $\begin{array}{l}\text { TOTAL NO. OF } \\
\text { PEOPLE INTERVIEW }\end{array}$ & $\begin{array}{l}\text { TOTAL NO. OF } \\
\text { PATIENT }\end{array}$ \\
\hline \multirow[b]{3}{*}{1} & \multirow[b]{3}{*}{ Akpabuyo } & Heart attack & 1500 & 35 \\
\hline & & Mental disorder & 1500 & 30 \\
\hline & & asthma & 1500 & 12 \\
\hline \multirow[b]{4}{*}{2} & \multirow[b]{4}{*}{ Akamkpa } & Lung cancers & 1500 & 46 \\
\hline & & Strokes & 1500 & 33 \\
\hline & & Mental disorder & 1500 & 30 \\
\hline & & asthma & 1500 & 24 \\
\hline \multirow{3}{*}{3} & \multirow{3}{*}{ Odukpani } & Lung cancers & 1500 & 45 \\
\hline & & Heart attack & 1500 & 32 \\
\hline & & Strokes & 1500 & 26 \\
\hline \multirow[b]{4}{*}{4} & \multirow[b]{4}{*}{ Biase } & Heart attack & 1500 & 38 \\
\hline & & Strokes & 1500 & 25 \\
\hline & & Mental disorder & 1500 & 23 \\
\hline & & asthma & 1500 & 20 \\
\hline \multirow[b]{5}{*}{5} & \multirow[b]{5}{*}{ Ikom } & Lung cancers & 1500 & 40 \\
\hline & & Heart attack & 1500 & 38 \\
\hline & & Strokes & 1500 & 26 \\
\hline & & Mental disorder & 1500 & 26 \\
\hline & & asthma & 1500 & 20 \\
\hline \multirow{2}{*}{6} & \multirow{2}{*}{ Yarkulr } & Lung cancers & 1500 & 41 \\
\hline & & Heart attack & 1500 & 36 \\
\hline \multirow[b]{5}{*}{8} & \multirow[b]{5}{*}{ Boki } & Lung cancers & 1500 & 43 \\
\hline & & Heart attack & 1500 & 32 \\
\hline & & Strokes & 1500 & 25 \\
\hline & & Mental disorder & 1500 & 21 \\
\hline & & asthma & 1500 & 19 \\
\hline \multirow[b]{5}{*}{9} & \multirow[b]{5}{*}{ Ogoja } & Lung cancers & 1500 & 42 \\
\hline & & Heart attack & 1500 & 30 \\
\hline & & Strokes & 1500 & 25 \\
\hline & & Mental disorder & 1500 & 20 \\
\hline & & asthma & 1500 & 15 \\
\hline
\end{tabular}

Table 2a: total no. of patient with smoking related diseases (Akpabuyo to Ogoja)

\section{TOTAL NO. OF PATIENTS}

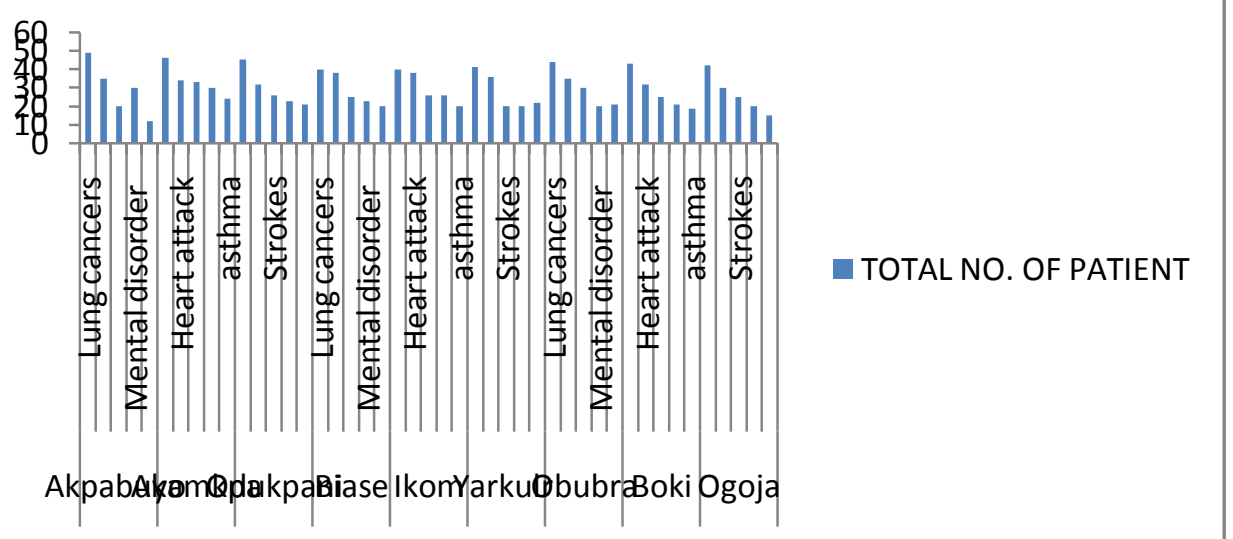

Fig. 3a: descriptive comparable bar chart of total no. of patient with smoking related diseases(Akpabuyo to 


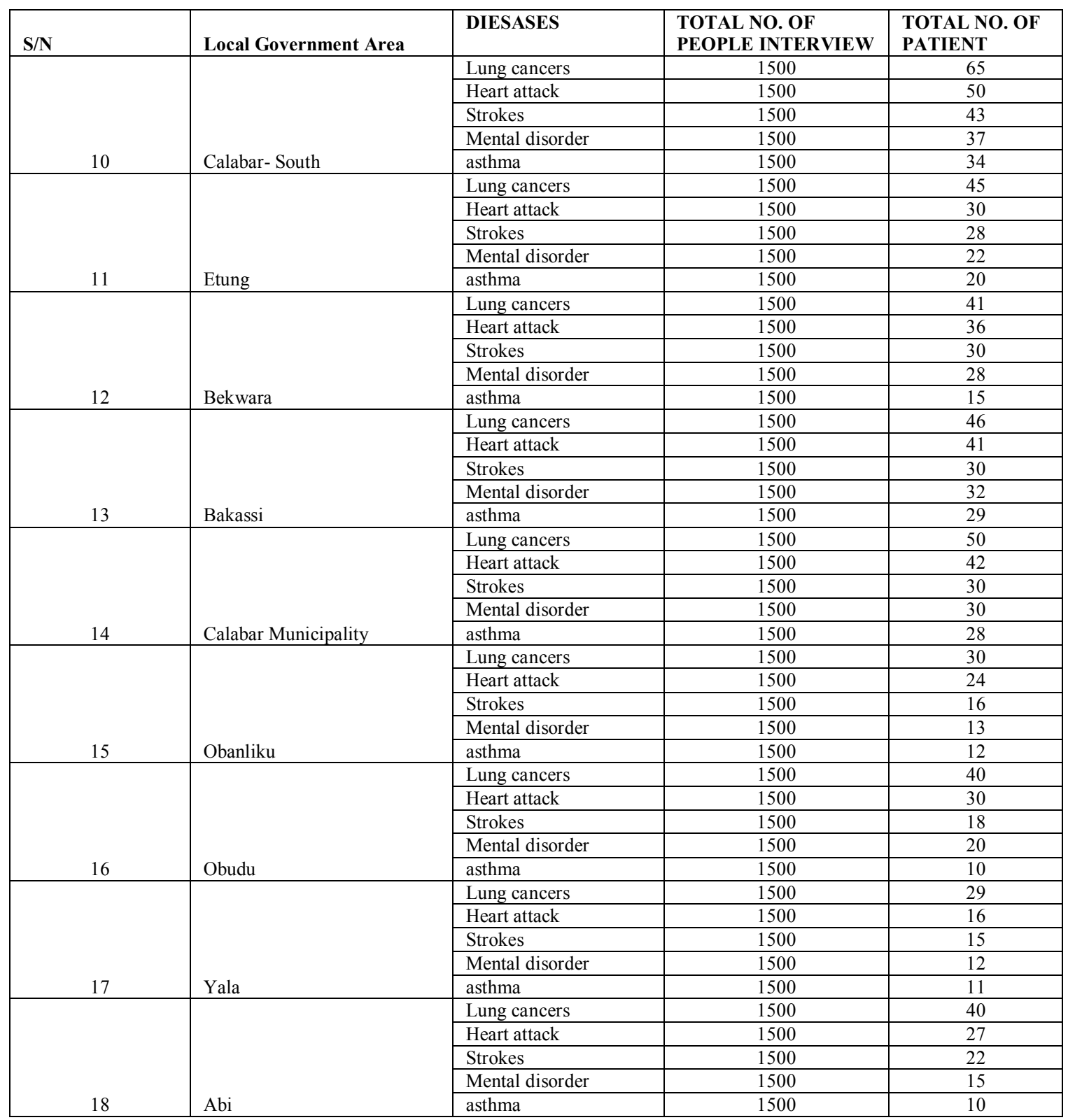

table $2 \mathrm{~b}$ : total no. of patient with smoking related diseases

\section{TOTAL NO. OF PATIENTS}

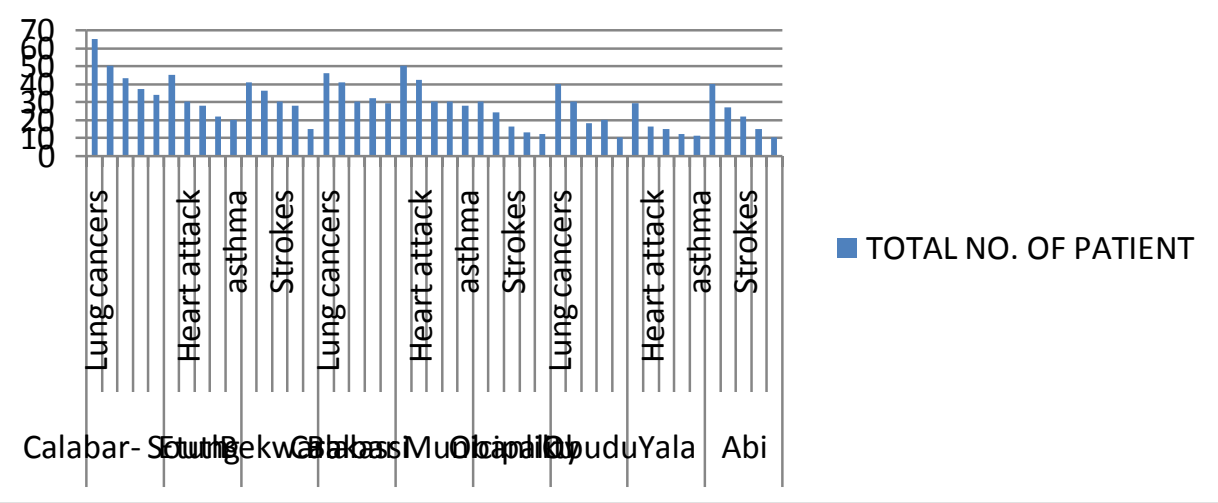

Fig. 3b: descriptive comparable bar chart of total no. of patient with smoking related diseases(Calabar-South to Abi) 


\section{Discussion of Result}

Based on the results of the valid questionnaires gotten, it was discovered that, the people smoked the following cigarettes: Pall Mall, Oris Slims Light, Dorchester International, Benson and Hedges, Rothmans Kingsize and St. Moritz. Tobacco is the single greatest cause of preventable death globally. The use of Tobacco leads mostly to diseases affecting the heart, liver and lungs. Smoking is a major risk factor for heart attacks, strokes, chronic obstructive pulmonary disease (COPD) (including emphysema and chronic bronchitis), and cancer (particularly lung cancer, cancers of the larynx and mouth, and pancreatic cancer). It also causes peripheral vascular disease and hypertension. The effects depend on the number of years that a person smokes and on how much the person smokes. Starting smoking earlier in life and smoking cigarettes higher in tar increases the risk of these diseases. Also, environmental tobacco smoke, or secondhand smoke, has been shown to cause adverse health effects in people of all ages

A high number of people smoke Pall Mall, because it is more affortable (cheap). Calabar South appears the highest in the smoking rate due to their high level of exposure and availability of jobs. Table 1, fig.1 and fig.2 recorded Yala Local Government Area has the least number of smokers perhaps due to its remote location and poor economic state of the community.

\section{Conclusions}

Cigarette smoking like conventional air pollution has also been linked to Decreases of lung function, increase of heart attacks, Respiratory diseases, cancer, asthma, and other health effects. Pollution also create odour and smog, diminishing the protective ozone layer and its contributions. In summary, the findings of these study provide additional evidence and strength to the existing literature on the adverse Environmental health effects, climate change and ambient air pollution, faced by people living in Cross River State and similar cities elsewhere. From The results of this investigation and considering the high level of cigerate related diseases, it is recommended that the Government bans smoking in publice places, ban the advertisement of any knid of cigerate and enforce punishment to offenders. The Government is also expected to enact and enforce the clean indoor air act, which restricks smooking to indoors, conduct site specific assessment of health risks from air pollutants emittes by smokers.

\section{Reference}

[1]. Agency for toxic substance and Disease registry http//ww.atsdr. cdc. gov/general/theair.html Accessed on $5^{\text {th }}$ February, 2013 by 5:30pm.

[2]. Air Pollution and respiration Health http.//www. cdc. gov/nceh/airpollution accessed on the $5^{\text {th }}$ February, 2013 5:59pm.

[3]. Air Pollution and respiratory health; centre for disease control and prevention http://www.cdc.gov. retrieved 21/07/2013;4:17pm.

[4]. Air pollution: http://www.niehs.nih.gov/health. retrieved 21/07/2013;05:15pm.

[5]. Air quality (out door) http:// haldon. ca/cms/one aspx? Portalld $=8310$ \& page $1 \mathrm{~d}=1247$ retrieved $2 / 5 / 2013$ at $6.01 \mathrm{pm}$.

[6]. Air Quality and Atmospheric and health. http://www.springer.com. Retrieved 21/07/2013; 4:015pm.

[7]. Air quality and health http://www.who. int/mediacentre/factsheets/fs313/en/index.html Accessed on the $5^{\text {th }}$ February, 2013.

[8]. Air Quality and health http://www.who.int/media. retrieved 21/07/2013; 05:10pm.

[9]. Air Quality: ministry of health; http://www.health.gov.bc. Retrieved 21/07/2013. 04:50pm.

[10]. Air Quality: Minnesota department of health. http://www.health.state. Retrieved 21/07/2013 4:08 pm.

[11]. Air Quality-pm2.5 information http://www.co.missoula. Retrieved 21/07/2013; 04:55pm.

[12]. Ambiant Air Pollution: Health Hazards to children http: pediatrics. aappublications. org/content 114/6/1699. full retrieved 2/5/2013: $4: 34 \mathrm{pm}$.

[13]. B.C. 's Air Quality Readings http.//www. bcairequality. ca/readings/index.html retrieved 2/5/2013, 5:26pm.

[14]. Bonfires, pollution control Air, clean Air Act. http://www.iwight.com. Retrieved 21/07/2013. 4:39pm.

[15]. CO2 transmitters http.//www. rotronic com/humidity - Measurement - feuchtemessing. retrieved 2/5/2013 at 5:49pm.

[16]. Current Air Quality in missoula http://www.missola. Retrieved 21/07/2013, 4:12pm.

[17]. Environmental Air Pollution Control system and precious metal Catalysts http://www. eas-inc.com accessed on the $5^{\text {th }}$ February, 2013 at $5: 48 \mathrm{pm}$

[18]. Environmental and Environmental studies: Air Quality National Academic of science: http://www.nap.edu. Retrieved 21/07/2013. $04: 59 \mathrm{pm}$.

[19]. Environmental Hazard and Health effects http://www. cda. gov $/$ nceh/ehhel Accessed on $5^{\text {th }}$ February, 2013 by $5: 44 \mathrm{pm}$

[20]. Environmental Health http://ha waii.gov/health environment Accessed on the $5^{\text {th }}$ February, 2013 at 4:30pm.

[21]. Environmental Health, Air Quality. http://www.health.gov.st. Retrieved 21/07/2013. 4:35pm.

[22]. Environment impact assessment (EIA) Niger Delta Development Commission Ministry of Environment Cross River State, Calabar (2010-2012) October Report 2012.

[23]. Environmental services protecting and restoring what matter most. http://www.battelle.org. retrieved 21/07/2013; 05:03pm

[24]. Igwe O. Ewona and Sunday O. Udo characteristic pattern of rainfall in Calabar Nigeria - A tropical coastal location (2008) Nigeria Journal of Physics 20(1) 2008.

[25]. Igwe O. Ewona, Emmanuel O. Obi and Ferdinand A. Kangba.Prospect of Biomass Energy in Niger Delta Region of Nigeria. 2011.

[26]. Indoor Air pollution: http://www.cieh.org. retrieved 21/07/2013, 04:45pm.

[27]. Indoor Air Quality $\{\mathrm{IAQ}\}$ in schools. http://www.health.state. Retrieved 21/07/2013. 04:53pm.

[28]. Indoor air quality http//en.wikipedia. org./wiki/indoor-air-quality Accessed on the $5^{\text {th }}$ February, 2013 at 5:26pm.

[29]. Indoor Air quality http://www. google. com. $\mathrm{ng} / \mathrm{search}$ ? $\mathrm{hl}=\mathrm{en} \mathrm{x}$ tbo $=1366 \mathrm{xbih}=5$ accessed on the $5^{\text {th }}$ February, 2013.

[30]. Minnesota Department of Health http/www health. state Mn. us/divs/eh/air/index. htm accessed on $5^{\text {th }}$ February 2013 by $5: 59 \mathrm{pm}$.

[31]. Osang, J.E, Obi E.O, Ewona, I.O Udoimuk A.B, Nnwankukwu. (2013) Review of Gas flaring Activities in Nigeria Delta Area of Nigeria http://www.ijsetr.org. 
[32]. OSANG, Jonathan. Eyire., OBI, E. O., Ewona, I. O., IOSR Journal of Electronics and communication Engineering (IOSR-JECE) eISSN:2278-2834, P-ISSN:2278-8735. Volume 6 issue 3 (May=June 2013) pp 16-22. www.iosrjournals.org/iosr-jese/pages

[33]. Osang. J. E, Ewona I.O, Obi E. O., Udoimuk A,B, Kamgba F.A (2013) analyses of Radiation and Rainfall pattern in Kano State Northern Nigeria (1978-2007). http://www.ijser.org.

[34]. Ozone and Air Quality. http://www.health.state. Retrieved 21/07/2013.

[35]. S.O.Udo, I.O. Ewona and L.E. Akpabio Global Solar Radiation Distribution and Utilization season at Ilorin, Nigeria (2008) Nigeria Journal of Physics 20(1) 2008

[36]. SMD Not Air Pencil ZT-2 http/www.teph.com/pencil.html Accessed on the $5^{\text {th }}$ February, 2013.

[37]. Sources of air pollutants http//www.google.com.ng/imgress? q=poor tairt quality and hl=en \& sa= Accessed on $5^{\text {th }}$ February, 2013. $5: 30 \mathrm{pm}$.

[38]. Chris E Ekpenyong1, E. O. Ettebong, E. E. Akpan1, T. K. Samson, Nyebuk E. Daniel ; Urban city transportation mode and respiratory health effect of air pollution: a cross-sectional study among transit and non-transit workers in Nigeria. International preventing over diagnosis conference. http://oas.services .bmj/ $/ \mathrm{c} / \mathrm{bm}$ retrieved on 05/08/2013.

[39]. O. Ewona and S. O. Udo, changes in some meteorological parameters in the Nigeria Delta Region of Nigeria between 1989 and 1996. Global Journal of pure and Applied Sciences vol. 17 No 1. 2011:61-70. Copyright Bachodu Science Co. Ltd printed in Nigeria ISSN 118-0579 www.globaljournalseries.com Emial:info@globaljournalseries.com

[40]. Prevalence of current tobacco use among adults aged $=15$ years (percentage). World Health Organization. Retrieved 09:45 AM $16 / 9 / 2013$.

[41]. Mayo report on addressing the worldwide tobacco epidemic through effective, evidence-based treatment". World Health Organization. p. 2. Retrieved 2013-01-02.

[42]. World Health Organization (2008). WHO Report on the Global Tobacco Epidemic 2008: The MPOWER Package. Geneva: World Health Organization. ISBN 92-4-159628-7. ${ }^{[p a g e n e e d e d]}$

[43]. Vainio H (June 1987). "Is passive smoking increasing cancer risk?". Scand J Work Environ Health 13 (3): 193-6. doi:10.5271/sjweh.2066. PMID 3303311.

[44]. Nichter M, Cartwright E (1991). "Saving the Children for the Tobacco Industry". Medical Anthropology Quarterly 5 (3): $236-56$. doi:10.1525/maq.1991.5.3.02a00040. JSTOR 648675.

[45]. World Health Organization (2008). The Global Burden of Disease (2004 Update ed.). Geneva: World Health Organization. ISBN 92-4-156371-0.

[46]. "WHO Report on the Global Tobacco Epidemic". World Health Organization. 2008.

[47]. "Nicotine: A Powerful Addiction." Centers for Disease Control and Prevention. http:/www.cdc.gov/tobacco. Retrieved 22/09/2013, 09:30am

[48]. Atmosphere of Earth. En.wikipedia.org. retrieved 22/09/2013 09:54am

[49]. Fowles J, Dybing E (December 2003). "Application of toxicological risk assessment principles to the chemical constituents of cigarette smoke". Tob Control 12 (4): 424-30. doi:10.1136/tc.12.4.424. PMC 1747794. PMID 14660781.

[50]. The health consequences of involuntary exposure to tobacco smoke: a report of the Surgeon General" (PDF). Atlanta, U.S., page 93: U.S. Department of Health and Human Services, Centers for Disease Control and Prevention, National Center for Chronic Disease Prevention and Health Promotion, Office on Smoking and Health. 2006. Retrieved 2009-02-15.

[51]. Environment Health Certificate www.unitforsight.org Retrieved 09:18am 14/09/2013S.E Uron, A. B. Antai and E.E OSim; symptoms and lung function values in Nigerian men and women exposed to dust Generated from crushing of Granite Rock in Calabar, Nigeria; www.bioline.org.br Retrieved 09:22am 14/09/2013.

[52]. Onyemaechi C. Nweke and William N. Sanders III; Morden Environmental Health Hazards: a public Health Issue of Increasing significance in Africa (2009) environmental health prepect 2009 June; 117(6):863-870. Retrieved 9:40am 14/09/2013.

[53]. Robert D. Bullard (ph.D.); poverty, pollution and Environmental Racism strategies for building health and sustainable communities www.ejrc.cau.edu. Retrieved 11:39am 14/09/2013.

[54]. Health Effects of Tobacco:en.wikipedia.org. retrieved on 10:43pm;15/09/2013. 